\title{
Innovation for Biomotor Training and Football Techniques
}

\author{
Fauzi Fauzi $^{1}{ }^{*}$ Siswantoyo Siswantoyo ${ }^{1}$, Danang wicaksono ${ }^{1}$, Nawan Primasoni ${ }^{1}$ \\ ${ }^{I}$ Faculty of Sport Sciences, Universitas Negeri Yogyakarta, Yogyakarta, Indonesia \\ *Corresponding author.Email: fauzi@uny.ac.id
}

\begin{abstract}
This study aims to develop individual biomotor training tools and soccer techniques in the sport of football by integrating with technology. Research and development was used in this study. The development of this individual training tool is carried out in several stages, namely: (1) preliminary study, (2) product manufacture, (3) expert validation and revision, (4) product trial; small-scale trials/revisions and large-scale trials/revisions, and (5) the final product. Small-scale and large-scale trials were conducted at the Faculty of Sports Science, Yogyakarta State University. The data collection technique used in this study was an instrument in the form of an assessment sheet. The data analysis technique of this research is descriptive qualitative and descriptive quantitative. The result of this research is that a tool for individual football passing and physical training has been developed which is equipped with a programming box. The tool developed is suitable to be used to support training in football, it is based on expert judgment, namely expert percentage of $87.9 \%$ is in the good/decent category. Based on the small group trial, the percentage of $83.6 \%$ was included in the good/decent category and the large group trial of $89.3 \%$ was included in the very good/decent category. The results of the development of independent science and technology-based football passing and physical training media are effective tools for soccer coaches and children.
\end{abstract}

\section{Keywords: Biomotor, Football}

\section{INTRODUCTION}

Forming a good football player and achievers, of course, is not as easy as imagined. Achievements cannot be achieved in a short time, but require long planning, implementation and evaluation. Gradual training is needed and by monitoring talent according to the specified age. It is very important to know the child's ability to perform movements and physical ability to adapt to the body to compete. The tools used to measure children's abilities are of course different from adults. It takes a measuring tool that is precise and safe for children. It took a very long time to become a professional player, reported by The Science of Sport in an article entitled Talent, training and performance: The secrets of success, Genes vs. training stated that "the average international football athlete has spent 4000 training hours. hours" Of course, enough practice must be balanced with measurements to determine the level of difference from time to time.

One of the most common movements in football is kicking. Players who have good kicking techniques will be able to play efficiently. The purpose of kicking the ball is to pass (pass), shoot at the goal (shooting at the goal), and sweep (keep the ball away from one's own goal) and to thwart the opponent's attack (sweeping). Passing is one of the most important elements in a football game. The role of passing in the game of football is to move the ball in different directions, and not infrequently passing is also used to enter the ball into the goal [1]. [2] kicking the ball aims to (1) give the ball to a friend or pass the ball, (2) to put the ball into the opponent's goal or score a goal, (3) to revive the ball after an offense such as a free kick, corner kick, penalty kicks and so on, and (4) to make clearing or clearing by sweeping dangerous balls in their own area or in an effort to stem the opponent's attack in their own defence area.

Physical condition is a unified whole of components that cannot be separated, both improvement and maintenance. This means that in an effort to improve physical conditions, all these components must be developed. Although it is done here and there with a priority system according to the conditions or status needed, it is necessary to know next is how an athlete can know the status and state of his physical condition at a time [3]. The components of physical condition are strength, endurance, muscle 
explosive power, speed, flexibility, agility, coordination, balance, accuracy, reaction [3].

The Law of the Republic of Indonesia number 3 of 2005 concerning the National Sports System in article 74 paragraph 1 states that the Government, local governments, and/or communities carry out the development of science and technology in a sustainable manner to promote national sports. The development of science is always followed by the development of technology. Technology is a systematic study of techniques for making and working things, while science is a systematic effort to understand and interpret the world [4].

Science and technology have an important role in the development of football. With the existence of science and technology, activities that used to be difficult can now be done easily. Science and technology have a positive impact on the world of football. The use of science and technology is marked by the development of supporting tools or media in football. Quoting from the official FIFA website, the implementation of science and technology that has been carried out includes goal line technology, video assistant refere, Electronic performance and tracking systems (EPTS). In the training process, there are media that have been developed, such as rebound grip. However, the development of media that uses technology in football is still mostly carried out by developed countries.

Indonesian football is one of the countries with soccer players who have poor passing accuracy. The results of a study [5] showed that the level of passing accuracy of local athletes of the 2017 Indonesian professional football league 1 was in the "very poor" category of $3.70 \%$ (4 athletes), "less" category of $30.55 \%$ (33 athletes), the "medium" category was $41.66 \%$ (45 athletes), the "good" category was $12.96 \%$ (14 athletes), and the "very good" category was $11.11 \%$ (12 athletes). From the data, it can be seen that level one soccer athletes in Indonesia are still dominated by athletes with very low, low and moderate levels of passing accuracy with a percentage of $75.91 \%$, while the good and very good categories are only $24.07 \%$. To be able to master accurate passing techniques, special training is needed and tools that can provide accuracy when kicking are needed.

Physical exercise is very boring and tiring especially after several months of training. Physical exercise needs an interesting tool to ward off boredom. Coaches know the talent of football players by observing during matches that are still very subjective in their assessment [6]. It is a good tool used to assess valid and reliable talent. Former Indonesian National Team Physiotherapist, Matias Ibo, said that the physical fitness of the players in the Red and White squad is a classic problem that always repeats itself. Including the current coach of the Indonesian national team, Shin Tae Yong, who said that the Red and White players were only strong enough to play for 20 minutes. The players have responsibility for the condition of their own bodies and are required to always be in good shape as athletes. Including regulating nutritional intake, sleep time, rest and the volume and intensity of exercise every day. All depends on each individual. Some are self-aware, some are not. There are players who spend their free time in the gym, self-medicating physiotherapy or consulting a doctor. Therefore, regular, interesting and easy physical exercise needs to be done by every individual.

\section{METHODS}

The method used in this study is research and development, which produces a certain product [7]. The assessment of the products made is assessed by 5 experts. Small-scale product trials were conducted at the UNY football school on 15 children aged 12 years, and large-scale trials were carried out with 40 children

\section{RESULTS}

The product is assessed by experts and gets a percentage of $87.9 \%$ in the good/decent category. Some of the inputs obtained include the limitations and how to set the training time, the calculation of the number and time that can be displayed and stored in memory. In the small-scale trial, the percentage of $83.6 \%$ was included in the good/decent category and the large group trial of $89.3 \%$ was included in the very good/decent category.

In the development of passing training aids and biomotor components, several basic theoretical supports are used. The theory of physical training and the theory of basic passing techniques are an important part in designing this product. Both of these theories strongly support the creation of a tool that is made. Physical exercise of football players needs to consider the intensity, frequency, duration, interval, recovery supported by training principles. This innovative tool for passing and biomotor training consists of several components, namely: (1) Arduino nano is a small microcontroller development board, (2) DFPlayer Mini is an audio file player module, (3) Jumper is a jumper cable called Male to Male, (4) Mini USB is a standard connector for mobile devices, (5) Ribbon cable is a connecting conductor, (6) perforated PCB is a circuit board that already has small holes for placing various electronic components, (7) card memory is a digital data storage memory, (8) speaker system is an electroacoustical transducer that converts electrical signals into sound vibrations, (9) LCD is a type of display media that uses liquid crystals as the main viewer, (10) Laser is a mechanism of a device. which emits electromagnetic radiation in the form of light, 
(11) LDR sensor is one type of resistor that can experience $\mathrm{i}$ change in resistance when experiencing a change in light reception

\section{DISCUSSION}

The progress of science and technology is growing rapidly lately. This is indicated by the number of new innovations that have emerged in various disciplines. Sport is an applied science that is affected by the existence of technology to support when carrying out a sporting activity. Achievement sports are physical activities carried out to achieve the highest achievement targets. Achievement sports require a lot of support from various disciplines in order to achieve maximum performance. Technology in party sports is used by coaches and athletes to support the training process to the maximum. Technology will help athletes achieve maximum performance. Many developed countries or professional football clubs, especially in Europe, use technology in the training process. In contrast to developing countries such as Indonesia, which still minimally apply technology in sports. What is even more sad is the early age clubs that have not been touched by technology in the training process. Researchers create and integrate technology in the training and evaluation of early childhood children, especially the football branch.

Technology plays an important role in helping the progress of achievement in the field of sports. The use of science and technology is marked by the development of supporting tools or media in football. Quoting from the official FIFA website, the implementation of science and technology that has been carried out includes goal line technology, video assistant referee, Electronic performance and tracking systems (EPTS), Longomatch, a match analysis system that can help football coaches [8]. Footbonaut is a football training tool that make it easier for coaches to improve athletes' abilities [9]. In the training process, there are media that have been developed, such as rebound grip. Reference [10], that the media as everything that can be used to channel messages and send messages to the recipient of the message, so that it can stimulate thoughts, feelings, attention and interest and children's attention in such a way that the practice process takes place effectively and efficiently as expected. Research products are made to create an interesting exercise, exercises that will be clearer for children to understand, exercises can be done independently and varied training processes for children.

Children will be able to improve the quality of passing and physical football with an effective, efficient, systematic and measurable training process. This product is used for independent passing and physical training. The development of this individual football passing and physical training aid media was produced as a training medium for coaches and football players in training individual football passing and physical training. This research is a manifestation of the implementation of science and technology in the world of football. This product was developed in collaboration between researchers, experts in the field of science and technology and football practitioners. The product begins with a description of the performance of the training media and then continues with the selection of the required electronic components. The last stage is testing the media to assess where the shortcomings are and make sure the media is ready for use.

In modern football, there is a change in speed combined with short passing [11], [12]. Passing is a skill that is often used in football, both short passing and long passing [13]. The speed of passing made will correlate with the speed of the football game [11], [14], [15]. This product is made to practice passing techniques which are very much needed in the game of football. Passing down short is a technique used in using this product.

In the last decade, the technology in football which uses computers to detect and track player movements has been very developed [16]. Including how computers with the help of GPS know the movements of football players. The products made in this study have many benefits for the world of training, especially football. Some of the benefits obtained include: (1) it is an alternative that helps practice football by utilizing digital media, (2) coaches can improve children's passing skills by measuring and practicing independently, (3) this media can be used easily and not requires a large area, (4) This media attracts children to practice individually. Technology is able to make athletes more independent in carrying out exercises so that abilities can be developed properly (July, 2019). One of the successes in the world of coaching is by applying technology in the training process [17].

The technology applied in football is still limited to elite professional clubs ([18], [19]). Currently smartphones, tablets, smart watches have become items that strongly support football, especially in tracking the GPS (Global Positioning System) function. Then it develops to know the movements and activities carried out. Kicking motion has been very developed and has been widely studied, usually using the help of a camera robot that helps to analyze [20]. Elite competition management is also competing to create technology that is integrated with football ([21], [22]). The problem for coaching early childhood, especially in Indonesia, which is indeed short of funds, is the high price. This makes it a challenge how football from an early age to adulthood 
has been integrated with technology. This product was created at a relatively low cost, so that it can be applied and held on a more mass basis. The product will be very useful if the children have it at home so that the practice time is not limited.

Passing training aids and biomotor components were created and developed with the aim of creating a new alternative for passing exercises, especially under passing exercises and biomotor components that support football players. The development of passing training aids and biomotor components is carried out through several stages, such as a preliminary study conducted to find out and obtain data about the equipment used for passing exercises independently, problems in passing exercises, physical exercise problems, as well as the importance of passing and biomotor abilities to soccer player. To obtain a good technique, a child must practice regularly and perform these movements repeatedly so that they will get movement automation. However, the problem with soccer passing practice is that you need a friend to do the exercises. This is the advantage of a product that is made to be able to practice independently and will form motion automation by practicing at any time.

The analysis of a match that is carried out can be used by the coach to make specific exercises [23]. Likewise, this product can be used as a means of evaluating an exercise. A coach is someone who can help overcome technical and physical problems for football players. Some of them already understand the basic concepts of soccer practice, but the tools used for individual passing and integrated with technology are still very minimal. Trainers who do exercises with a technological approach will be more organized, measurable and simplified, but need tools that support these exercises. The tools needed by a coach, of course, besides being able to improve the technique and physicality of players are that they can be done anywhere easily and safely.

\section{CONCLUSION}

The innovative product of individual practice tools and biomotor components is an alternative training medium that allows children to practice independently with data from training results. The results of the development of independent science and technologybased football passing and physical training media are effective tools for soccer coaches and children. Positive feedback about this media plays an important role in the world of sports, especially football and is expected to be able to improve the quality of football in Indonesia, because it will be easier to train football players' passing and physicality so that they can improve the quality of passing and physical players to achieve maximum performance

\section{REFERENCES}

[1] Danny Mielke, Dasar-dasar Sepakbola. Bandung: Pakar Raya, 2007.

[2] Parrish, M., Essential soccer skills: key tips and techniques to improve your game, 1st ed. New York: DK Publising, 2011.

[3] Sajoto, Moh., Peningkatan dan Pembinaan Kondisi Fisik Dalam Olahraga. Semarang: Dahara Price, 1995.

[4] Robert Angus Buchanan, Sejarah teknologi. Yogyakarta: Pall Mall, 2006.

[5] Ikhsan, S., Tingkat Akurasi Passing Atlet Lokal Sepakbola Profesional Indonesia Liga 1 2017. Yogyakarta State University, 2018.

[6] Kokstejn, J., \& Musalek, M., "The relationship between fundamental motor skills and game specific skills in elite young soccer players," Journal of Physical Education and Sport, 2019, vol. 19, no. 37, pp. 249-254.

[7] Borg, W.R \& Gall, M.D Gall, Educational Research. An Introduction. 5th ed., New York: Longman, 1983.

[8] Rizki Apriliyanto, "Sofware Analisis Sepakbola," Jurnal Ilmiah Pengabdian Kepada Masyarakat, 2021, vol. 21, no. 2, pp. 117-121.

[9] Vogt, T., Horn. S., Grannan, A. M., \& Aurnou, J. M., “Jump rope vortex in liquid metal convection," Proceedings of the National Academy of Sciences of America, vol. 115, no. 50, pp. 12674-12679, November 212018.

[10] Sadiman, A., Media Pendidikan. Jakarta: Raja Grafindo Persada, 2007.

[11] Barnes, C.,Archer, D. T., Hogg, B., Bush, M., \& Bradley, P. S., "The evolution ofphysical and technical performance parameters in the English Premier League," International Journal of Sports Medicine, 2014, vol. 35, no.13, pp. 10951100 .

[12] Dellal, A.,Wong, D. P.,Moalla, W., \& Chamari, K., "Physical and technical activity of soccer playersin the French first league-with special reference to their playing position," International Sport Med Journal, 2010, vol. 11, no. 2, pp. 278-290.

[13] Saal, C., Zinner, J., Fiedler, H., Lanwehr, R., \& Krug, J., "Reliability and validity of a soccer passing test using the Footbonaut," German Journal of Exercise and Sport Research, 2018, vol. 48, no. 3, 334-340.

[14] Bush, M., Barnes, C., Archer, D. T., Hogg, B., \& Bradley, P. S., "Evolution of match performance parameters for various playing positions in the English Premier League," Human Movement Science, 2015, vol. 39, pp. 1-11.

[15] Wallace, J. L., \& Norton, K. I., "Evolution of world cupsoccer final games 1966-2010: game structure, speed and play patterns," Journal of Science andMedicine in Sport, 2014, vol. 17, no. 2, pp. 223-228.

[16] Buchheit, M., Allen, A., Poon, T. K., Modonutti, M., Gregson, W., \& Di Salvo, V., "Integrating different tracking systems in football: multiple camera semi-automatic system, local position measurement and GPS technologies," Journal of Sports Sciences, 2014, vol. 32, no. 20, pp. 1844-1857.

[17] Ababill, S. Adi2 , N. R. Fadhli, "Pengembangan Media Latihan Teknik Dasar Bulutangkis Berbasis Aplikasi Android Untuk Atlet Pemula," Indonesia Performance Journal, 2019, vol. 3 .

[18] Harley, J. A., Lovell, R. J., Barnes, C. A., Portas, M. D., \& Weston, M., "The interchangeability of global positioning system and semiautomated video-based performance data during elite soccer match play," Journal of Strength and Conditioning Research, 2011, vol. 25, pp. 2334-2336.

[19] Randers, M., Mujika, I., Hewitt, A., Santisteban, J., Bischoff, R., Solano, R., Mohr, M., "Application of four different football match analysis systems: A comparative study," Journal of Sports Sciences, 2010, vol. 28, pp. 171-182. 
[20] Yoshiyuki Tanaka, "Manipulability Analysis of Kicking Motionin Soccer Based on Human Physical Properties," 2006 IEEE Conference on Systems, Man, and Cybernetics October 8-11, 2006, Taipei, Taiwan.

[21] Cummins C, Orr R, O’Connor H, West C., "Global positioning systems (GPS) and microtechnology sensors in team sports: a systematic review," Journal of Sports Med. 2013, vol. 43, no. 10, pp. 1025-1042.
[22] Robertson P.S., "Man \& machine: adaptive tools for the contemporary performance analyst," J Sports Sci, 2020, vol. 38 , no. 18 , pp. $2118-2126$.

[23] Di Salvo, V., Baron, R., Tschan, H., Calderon Montero, F. J., Bachl, N., \& Pigozzi, F., "Performance characteristics according to playing position in elite soccer," International Journal of Sports Medicine, 2007, vol. 28, pp. 222-227. 